University of Nebraska - Lincoln

DigitalCommons@University of Nebraska - Lincoln

Mammalogy Papers: University of Nebraska

State Museum

Museum, University of Nebraska State

6-14-2001

\title{
Evolution of a Scientific Meeting: Eighty Annual Meetings of the American Society of Mammalogists, 1919-2000
}

Hugh H. Genoways

University of Nebraska - Lincoln, h.h.genoways@gmail.com

Patricia W. Freeman

University of Nebraska - Lincoln, pfreeman1@unl.edu

Follow this and additional works at: https://digitalcommons.unl.edu/museummammalogy

Part of the Higher Education Commons, Science and Mathematics Education Commons, and the Zoology Commons

Genoways, Hugh H. and Freeman, Patricia W., "Evolution of a Scientific Meeting: Eighty Annual Meetings of the American Society of Mammalogists, 1919-2000" (2001). Mammalogy Papers: University of Nebraska State Museum. 12.

https://digitalcommons.unl.edu/museummammalogy/12

This Article is brought to you for free and open access by the Museum, University of Nebraska State at DigitalCommons@University of Nebraska - Lincoln. It has been accepted for inclusion in Mammalogy Papers: University of Nebraska State Museum by an authorized administrator of DigitalCommons@University of Nebraska Lincoln. 


\title{
EVOLUTION OF A SCIENTIFIC MEETING: EIGHTY ANNUAL MEETINGS OF THE AMERICAN SOCIETY OF MAMMALOGISTS, 1919-2000
}

\author{
Hugh H. Genoways* and Patricia W. Freeman \\ University of Nebraska State Museum, W436 Nebraska Hall, University of Nebraska-Lincoln, \\ Lincoln, NE 68588-0514
}

The American Society of Mammalogists has held 80 annual meetings between 1919 and 2000. These meetings have been held in 32 states, the District of Columbia, Canada, and Mexico. At least 86 people have served as the chair or co-chair of the Local Committee planning the meetings. The number of technical presentations has grown from a low of 17 in 1921 to 340 in 1994. Symposia were an early feature of annual meetings but did not become a regular feature until 1971. Poster presentations were introduced in 1979 and reached a high of 195 posters at the 1994 annual meeting. Two trends are evident in the analyses of presentation data from annual meetings. There has been a major increase in the number of presentations, especially since 1968, when the number of presentations first exceeded 100. The other trend is the significant increase of participation of women scientists in the annual meetings of the Society. This trend had its origins in the late 1960s and was significantly aided by the addition of poster sessions, which have been popular venues for women scientists to present their research results. However, women are not as well represented as organizers or invited participants in symposia.

Key words: American Society of Mammalogists, annual meetings, history of science, mammalogy, men in science, scientific meetings, women in science

The incorporators of the American Society of Mammalogists stated that "the particular objects and business of this Society shall be the promotion of the study of mammalogy by the publication of a serial and other publications, by aiding research, and by engaging in such other activities as may be deemed expedient" (Journal of Mammalogy 4:271-272, 1923). One of the activities that has been "deemed to be expedient" since the organizational meeting held in Washington, D.C., in 1919 has been the holding of annual meetings of the Society. Annual meetings along with the publication of the Journal of Mammalogy have served as the primary venues for presentation of scientific research on mammals and exchange of scientific ideas. Annual meetings

\footnotetext{
*Correspondent: hgenoways1@unl.edu
}

also have been sites for conducting business of the Society and recognition of students and contributions of members.

Much of the history of the American Society of Mammalogists has been well documented by Davis (1969), Hoffmeister (1969a, 1969b), Hoffmeister and Sterling (1994), and several of the other chapters in Birney and Choate (1994). However, only 1 paper has focused partially on the annual meetings of the Society (Gill and Wozencraft 1994). With the final meeting of the 2nd millennium in 2000 corresponding with the 80th annual meeting of the Society, it is an appropriate time to look back at the growth and changes that have occurred in these meetings.

\section{WHEN}

The organizational meeting of the American Society of Mammalogists was held at 
the National Museum in Washington, D.C., 3-4 April 1919. H. H. T. Jackson was chair of the Organizing Committee (Table 1). The next 18 meetings were held in April or May. The 1st meeting to deviate from that pattern also was the 1st to take place on the West Coast, being held at the University of California, Berkeley, 19-23 July 1938. From 1939 through 1952, the dates that the meetings were held varied greatly, with some meetings being held in March, April, June, and August. Thereafter, all meetings of the Society have taken place in June.

Only 80 annual meetings were held between 1919 and 2000 because there were 2 years during World War II when meetings were not held. The 25th annual meeting was planned for 27 April to 1 May 1943 to be held at the Carnegie Museum, Pittsburgh, Pennsylvania, with J. K. Doutt as the chair of Local Committee (Journal of Mammalogy 23:470, 1942). However, that meeting was cancelled "in accordance with requests from several federal agencies" (Journal of Mammalogy 24:124, 1943), but "on April 30, 1943, eight Directors assembled in the U.S. National Museum, Washington, D.C., for the purpose of conducting the routine annual business of the Society" (Journal of Mammalogy 24:419, 1943).

Again in 1944, holding a regular annual meeting was considered unwise, but a meeting of the board of directors was held to conduct business of the Society and to elect officers (Journal of Mammalogy 25:105, 1944). The 25th annual meeting was held at the American Museum of Natural History on 31 March 1944. Twenty-seven members attended the meeting, but no papers were presented, and no Standing Committee reports were given. E. Raymond Hall was elected president of the Society (Journal of Mammalogy 25:320, 1944).

The officers and directors voted not to have an annual regular meeting in 1945 but agreed to gather the officers and directors for a business meeting on 12 May 1945 at the Chicago Museum of Natural History (Journal of Mammalogy 26:109, 1945). Fi- nally in 1946, the 1st postwar regular meeting was planned and held at the Carnegie Museum on 18-20 April. J. Kenneth Doutt served as chair of the Local Committee (Journal of Mammalogy 26:451, 1945). Regular annual meetings with both presentations and business have been held since 1946 without a break through June 2000.

\section{WHERE}

Meetings have been held in 32 states and the District of Columbia in the United States. Three meetings have been held in Canada, in Toronto (1948), Winnipeg (1965), and Vancouver (1971), and 1 meeting was held in Mexico City, Mexico, in 1964. Meetings from 1919 to 1928 were all held at large museums on the East Coast, alternating among the United States National Museum, American Museum of Natural History, Academy of Natural Sciences, and Museum of Comparative Zoology. The 1st meeting not held on the East Coast was at the University of Michigan in 1929, and the 2nd was at the Carnegie Museum in 1935. The monopoly of the East Coast on the meeting sites was broken forever in 19381941, when 4 successive meetings were held on the West Coast (Berkeley, California, 1938), in the South (Baton Rouge, Louisiana, 1939), Rocky Mountains (Denver, Colorado, 1940), and in the upper Midwest (Chicago, Illinois, 1941).

The Society has met 9 times at the National Museum of Natural History (= United States National Museum), and the business meeting of 1943 also was conducted here. The majority of these meetings occurred in the early history of the Society, but the 75th anniversary of the Society was celebrated at the National Museum in 1994. Nine annual meetings of the Society also have been held at the American Museum of Natural History, including the 1944 wartime meeting at which no papers were presented. The most recent meeting in New York was the celebration of the first 50 years of the Society in 1969. Six other institutions have hosted multiple meetings, 


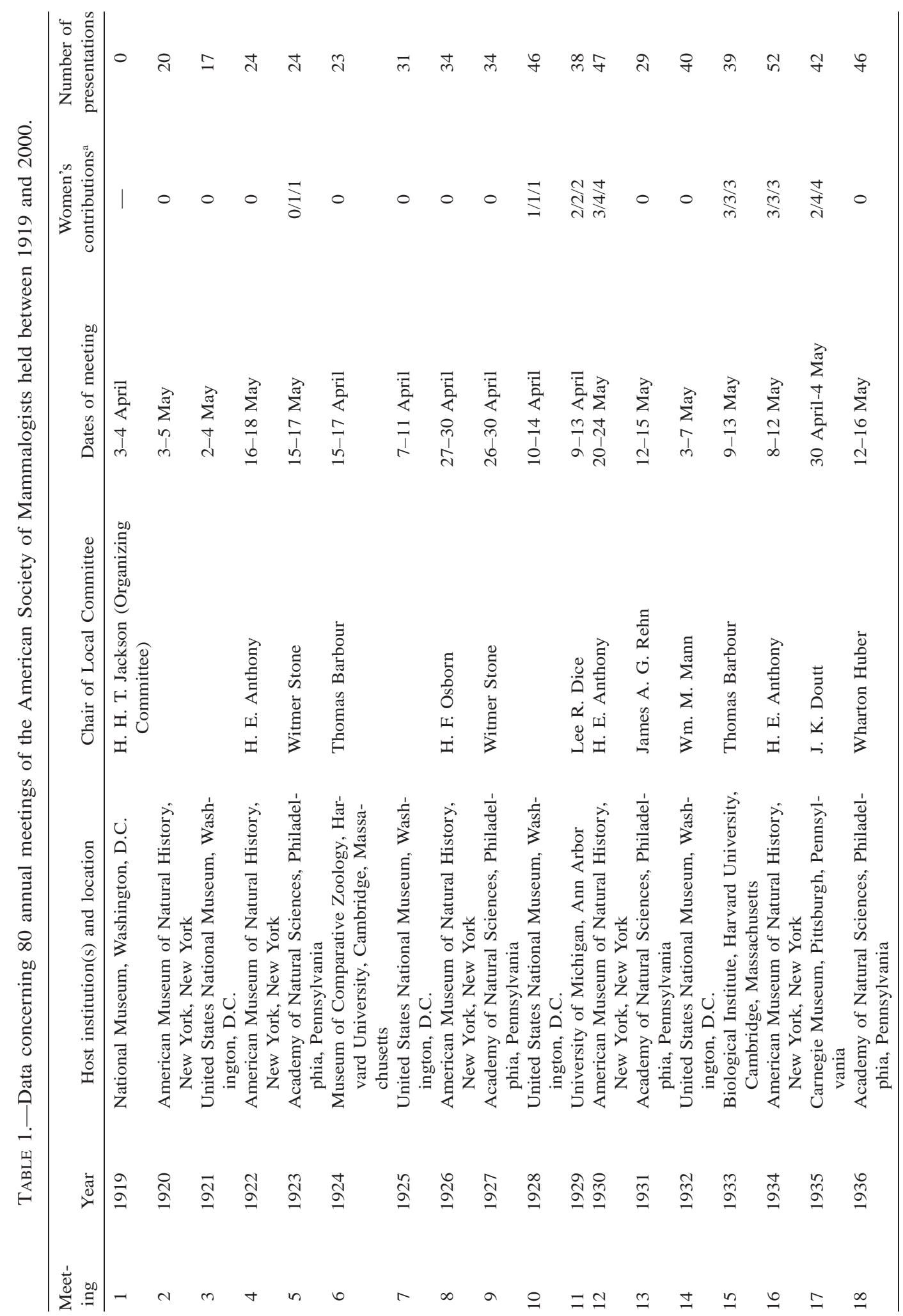




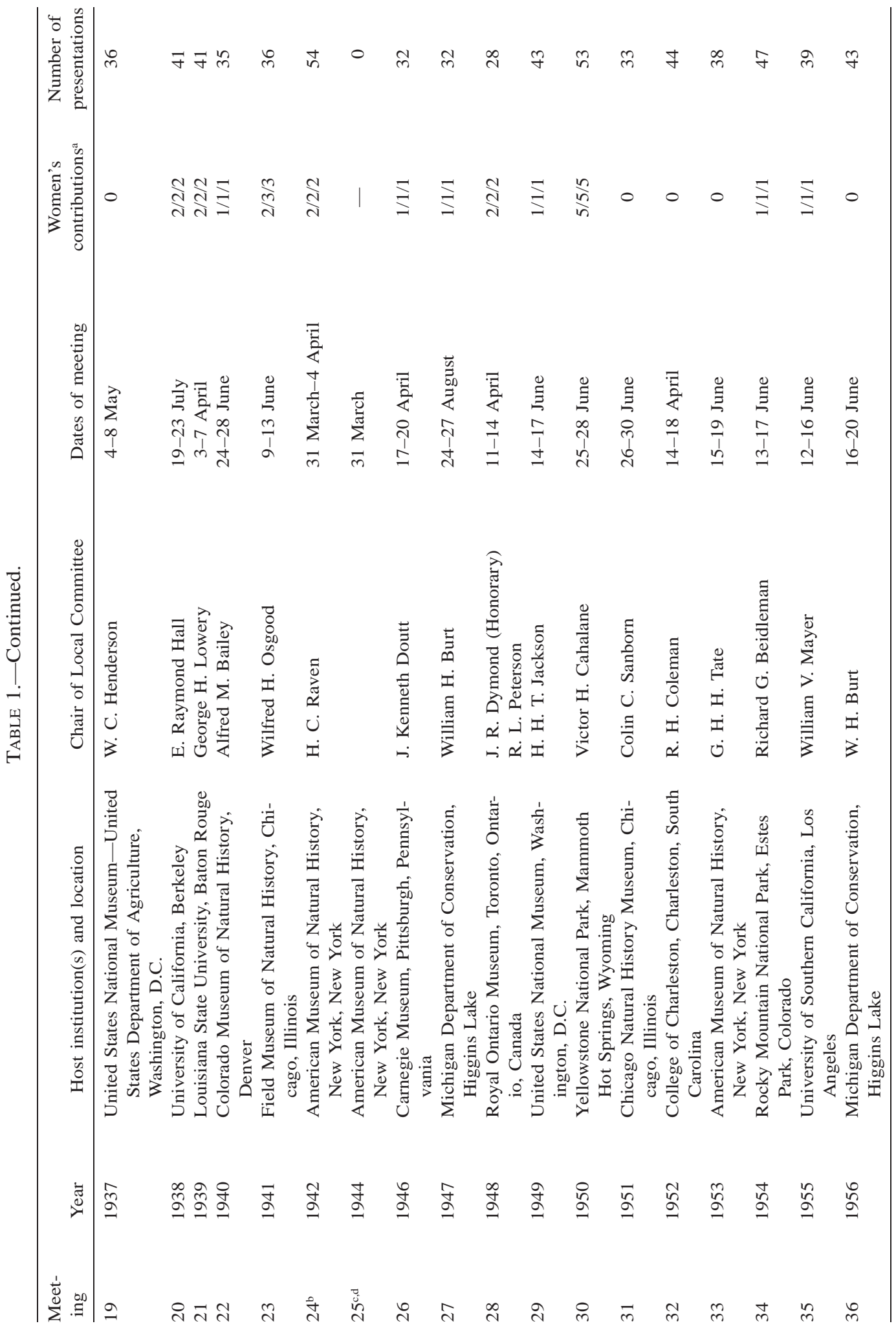




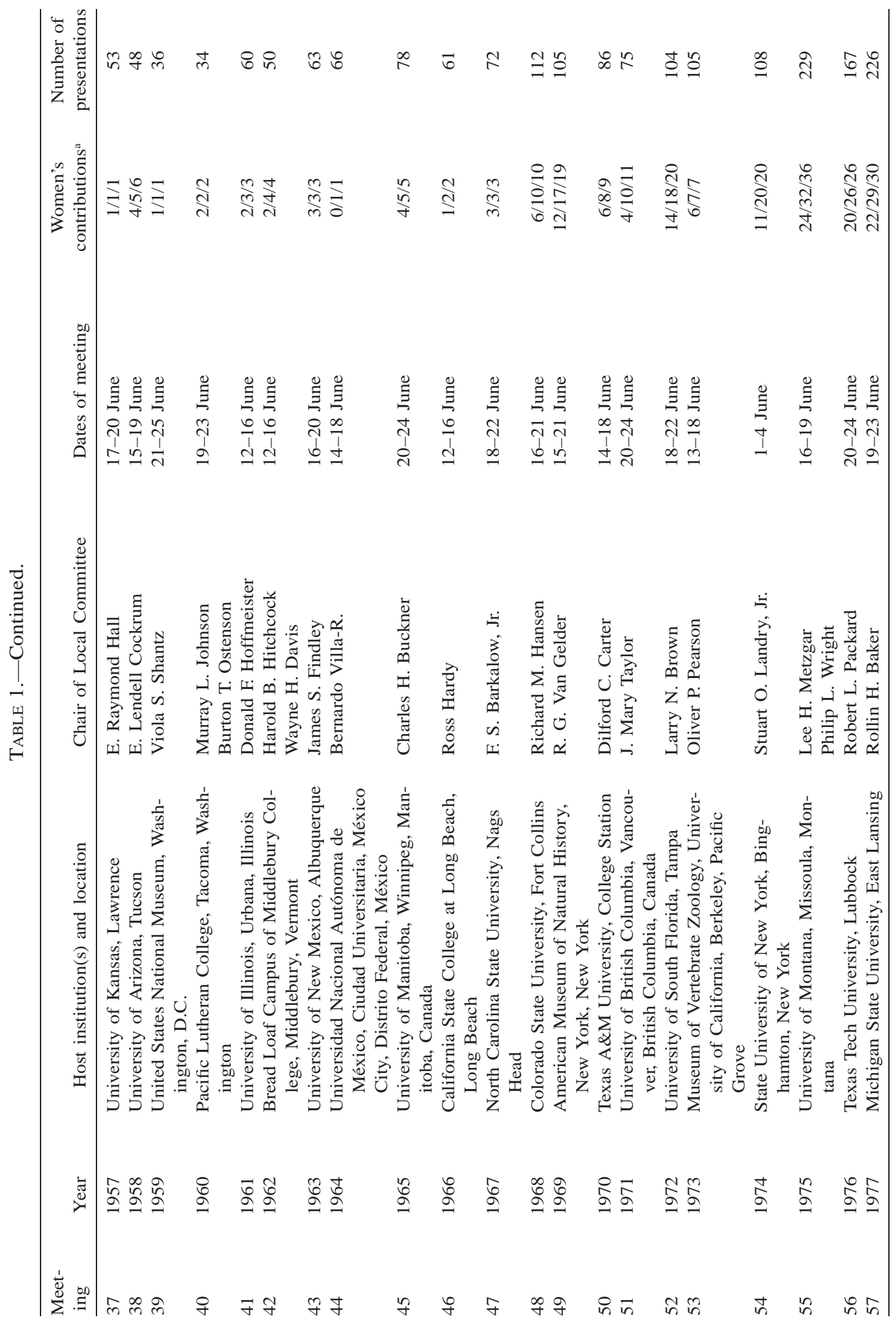




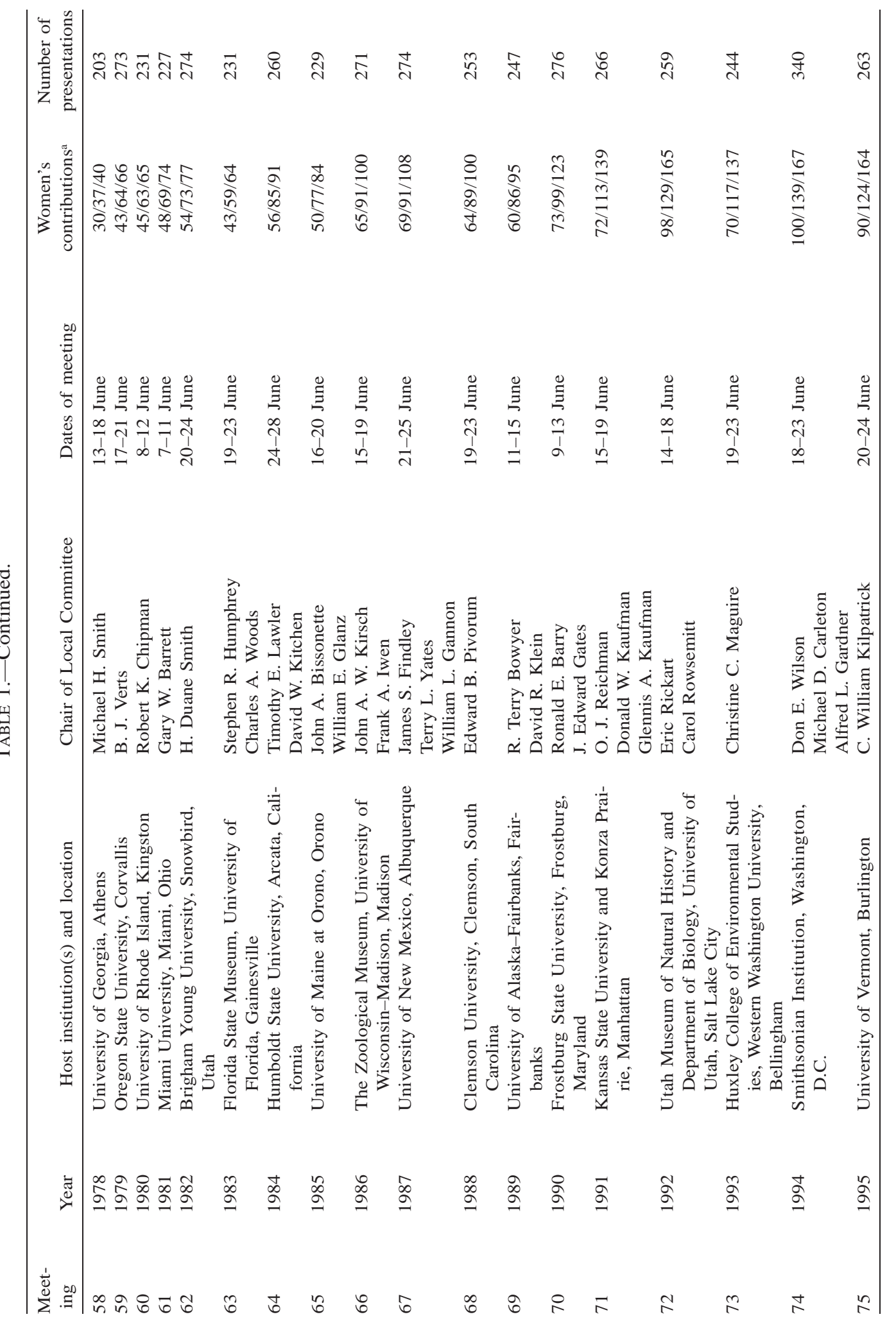




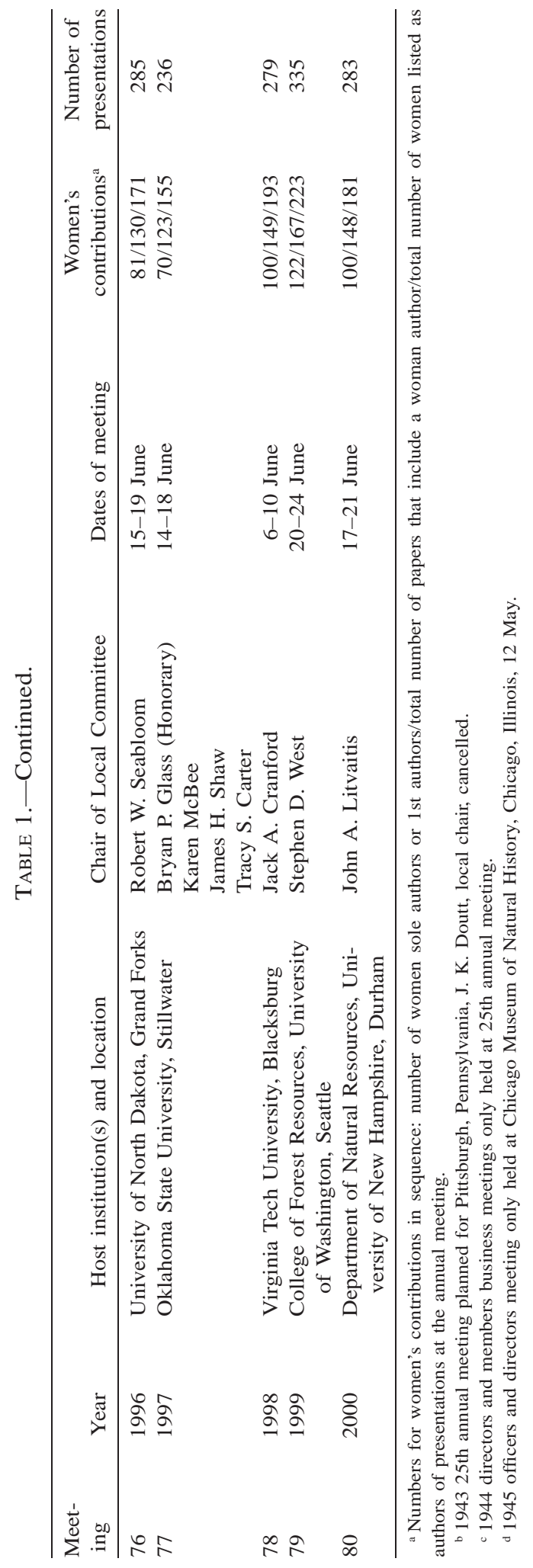

including the Academy of Natural Sciences of Philadelphia (1923, 1927, 1931, 1936), Harvard University (1924, 1933), Carnegie Museum (1935, 1946), University of California, Berkeley (1938, 1973), Michigan Department of Conservation (1947, 1956), and University of New Mexico (1963, 1987).

To resolve the issue of alternating meetings more equitably around North America, a map for the rotation of meeting sites was published in the Journal of Mammalogy $(55: 260)$ in February 1974. That map provided for meetings to rotate among 5 major regions of North America. What many of the members of the American Society of Mammalogists may not know is that this map was drawn by J. Knox Jones, Jr., as observed by one of us (H. H. Genoways). If members have ever wondered why the map looks a little strange-that is, the north-central region encompassing an area from Montana to Ohio-there is a good reason. Knox wanted to have the 1976 annual meeting in Lubbock, Texas, but he knew that Rollin Baker also wanted to have that meeting in East Lansing, Michigan. The decision on where the 1976 annual meeting would be held was made at Binghamton, New York, in 1974, with Missoula, Montana, having previously been selected for the 1975 meeting. With publication of the rotation system, Knox was able to argue that having meetings in Missoula and East Lansing in consecutive years would violate the newly established rotation system because both were in the north-central region. The 1976 annual meeting was held in Lubbock and the 1977 meeting in East Lansing. This maneuvering aside, the rotation system served the Society well throughout the remainder of the 20th century.

The impact of the rotation of meetings as compared with time periods prior to the institution of the system is shown in Table 2. Before 1938, meetings were held primarily in the northeast region. From 1938 through 1974, annual meetings visited all regions, but the southeast region (Virginia and Flor- 
TABLE 2.- Number of presentations at meetings of the American Society of Mammalogists categorized by the current regions used for annual meeting regional rotation.

\begin{tabular}{lcccrr}
\hline $\begin{array}{c}\text { Time } \\
\text { period }\end{array}$ & Northeast & Southeast & Southwest & West & North-central \\
\hline $1919-1937$ & 584 & 0 & 0 & 0 & 38 \\
$1938-1974$ & 494 & 261 & 457 & 355 & 426 \\
$1975-2000$ & 1,622 & 966 & 1,210 & 1,359 & 1,504 \\
Total & 2,700 & 1,227 & 1,667 & 1,714 & 1,968 \\
\hline
\end{tabular}

ida to Arkansas and Louisiana) was clearly underrepresented, as was the west region (from Alaska to California and Hawaii), but not to the same extent. Even with the rotation system (1975-2000), the southeast region remains underrepresented, but the system has successfully distributed meetings among the other regions.

As Hoffmeister (1969a) noted, in 1948 the Society decided that every 3rd meeting would be held at an "out-of-doors" location, but that schedule was never followed. However, at least 8 meetings have been held at such sites, including Higgins Lake, Michigan (1947, 1956); Yellowstone National Park, Wyoming (1950); Estes Park, Colorado (1954); Bread Loaf Campus of Middlebury College, Vermont (1962); Nags Head, North Carolina (1967); Asilomar Conference Center, Pacific Grove, California (1973); and Snowbird Ski Resort, Utah (1982). Although no out-of-door locations have been used in recent years, out-of-door activities are a feature of all recent annual meetings.

\section{WHO}

At least 86 people have served as the chair, co-chair, or honorary chair of the Local Committee (Table 1) to handle arrangements for the annual meeting. We can say only "at least" because no record of the Local Committee chair could be found for 5 years-1920, 1921, 1925, 1928, and 1944. We suspect that H. H. T. Jackson and other members of the scientific staff of the Biological Survey served in this role for several of these meetings because 3 of these early meetings were held at the National
Museum, and Jackson and then A. Brazier Howell were the corresponding secretaries until 1930. Eight people served as the chair of the Local Committee more than once, including H. E. Anthony (1922, 1930, 1934), H. H. T. Jackson (1919, 1949), Witmer Stone (1923, 1927), Thomas Barbour (1924, 1933), J. Kenneth Doutt (1935, 1946), E. Raymond Hall (1938, 1957), William H. Burt (1947, 1956), and most recently James S. Findley (1963, 1987). E. Raymond Hall holds the distinction as the only person to serve as the chair of the Local Committee at 2 different institutionsUniversity of California, Berkeley, and University of Kansas.

Viola S. Shantz was the 1st woman to serve as the chair of the Local Committee when the 1959 meeting was held at the National Museum. She was followed by 6 other women holding this important position for the annual meeting, including J. Mary Taylor (1971), Glennis Kaufman (1991), Carol Rowsemitt (1992), Christine Maguire (1993), Karen McBee (1997), and Tracy S. Carter (1997). Besides the trend of women taking an increasing leadership role in planning annual meetings, there has been a clear trend for the Local Committee to have cochairs rather than a single chair. Undoubtedly, this indicates the ever-increasing workload for the Local Committee as the meetings have become larger and more complicated.

\section{How}

A 38-page "Guide to Organizing the Annual Meeting of the American Society of Mammalogists" is maintained by the Program Committee to aid the Local Commit- 
tee in planning every detail of the annual meeting. The Guide was prepared by the Program Committee in 1978-1979 with J. Mary Taylor as chair. Prior to that time, information was passed from one Local Committee chair to the next, or decisions were re-created each year based on past experience of the Local Committee members. The Society has standardized most details of the annual meeting from registration, length of the oral presentations, size of posters, timing of business meetings, vendors, auction, and banquet to the run for research and group photograph. The Guide and its details may seem like the handy work of a group of overly compulsive scientists, but members do expect the annual meeting to run smoothly and follow a certain format. Each new chair of a Local Committee is eternally grateful to have such detailed instructions and solutions to many problems.

Those individuals and institutions wishing to host an annual meeting of the Society must extend the invitation 2 years in advance. The Program Committee solicits invitations and arranges for presentations at the 2nd business meeting at the annual meeting. This was not always true. Until 1970, meeting sites were selected only 1 year in advance. The development of the Guide and increasing the lead time for offering to host the meeting were done in direct response to the number of presentations at the meeting increasing greatly along with an increased numbers of attendees. Because hosting of national meetings has become big business for many universities, which employ a large number of staff members to make arrangements and host conferences, the Society also was required to reserve sites and dates further into the future.

\section{Technical Presentations}

The 1st technical presentation at an annual meeting of the American Society of Mammalogists was given by Vernon Bailey at the 2nd annual meeting on the topic of "Modern Methods of Mammalogical Field Work" (Jackson 1920). The last presenta- tion of the millennium was given by our current president, Thomas H. Kunz, and 3 students/colleagues, Tigga Kingston, Gareth Jones, and Zubaid Akbar, on "Ecomorphology of a Guild of Rhinolophid Bats from Malaysia-Evidence for Competitive Structuring." The 1st presentation by a woman at an annual meeting included Osa Johnson and her husband Martin when they showed films of African mammals at the 5th annual meeting in 1923 (Jackson 1923). The 1st technical presentation by a woman was at the 10th annual meeting in 1928, when Ruth D. Svihla spoke on "Breeding Habits of Reithrodontomys." Certainly, one of the most controversial technical papers ever presented at an annual meeting was "Zoological Subspecies of Man at the Peace Table" given by E. Raymond Hall at meeting in 1946. The returning veterans from World War II took considerable exception to the racial content of the paper, but they declined to interrupt the presentation. One of the most humorous and wellattended papers at any annual meeting was "How to Pick up a Skunk without Being Sprayed" by Richard G. Van Gelder at the meeting in 1977.

One of the trends in technical presentations at annual meetings is the vast increase in the number of presentations from a low of 17 at the 3rd annual meeting in 1921 to a high of 340 at the 74th annual meeting in 1994, which was closely followed by 335 at the 79th annual meeting in 1999 (Table 1). Within these extremes, there are milestones, such as the 1 st meeting with more than 50 presentations - the 16th annual meeting at the American Museum of Natural History in 1934. It was not until 1968 at Colorado State University that the number of presentations exceeded 100, but the 1st with over 200 presentations followed fairly quickly in 1975 at the University of Montana. The meetings in 1994 and 1999 were the only ones where the number of presentations exceeded 300.

The meeting at the University of New Mexico in 1963 was the 1st to feature a 


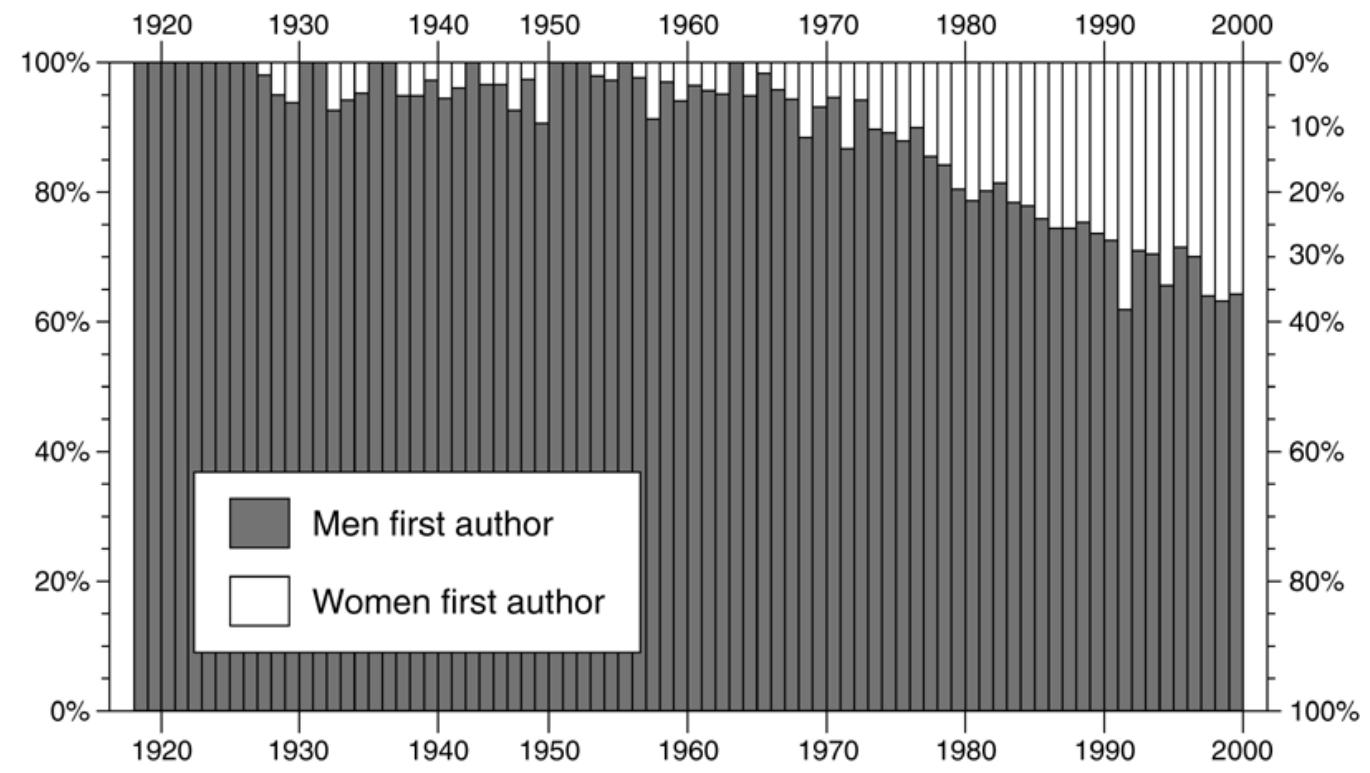

FIG. 1.-Relationship between percentage of presentations at annual meetings of the American Society of Mammalogists with women as 1 st authors compared with men as 1st authors.

double concurrent session of presentations, but concurrent sessions did not become a regular feature of annual meetings until 1972 at the University of South Florida. The 1st meeting to feature triple concurrent sessions was at the University of Montana in 1975, when the number of presentations went over 200 for the 1 st time. This situation was disliked by the membership, and the meetings thereafter were increased from 3 days of technical sessions to 4 days so that only double concurrent sessions would be necessary. However, in 1988 at the 68th annual meeting at Clemson University, triple concurrent sessions returned and became a permanent feature of the annual meetings.

A joint session, initially called the introduction session and later the plenary session (1980), was first held under the direction of President Sydney Anderson at the annual meeting at Texas Tech University in 1976. This session originally included only the 3 student honoraria winners, but a presentation by the previous year's Shadle Fellowship winner was added in 1980. In 1984 , the presentation by the previous year's recipient of the C. Hart Merriam Award was added to the plenary session. That presentation previously had been given at the annual banquet but with mixed success. After 2 years of an invited keynote address (1990-1991), the Merriam Award address was termed the keynote address, but it still was given in conjunction with the plenary session. Finally, at the 80th annual meeting, a keynote session was established that included presentations by the previous year's recipients of the Merriam and Joseph Grinnell Awards, to immediately follow the plenary session.

The other major trend that can be seen in these data (Figs. 1 and 2; Table 1) is the dramatic increase of participation of women scientists in the annual meetings of the American Society of Mammalogists. In the first 50 meetings of the Society, there were 15 years when there were no women on the meeting program. During that period, only at the 38th annual meeting at the University of Arizona in 1958 and at the 49th in New York in 1969 did presentations by women constitute over $10 \%$ of the program when just over $10 \%$ and $16 \%$ of the presentations, 


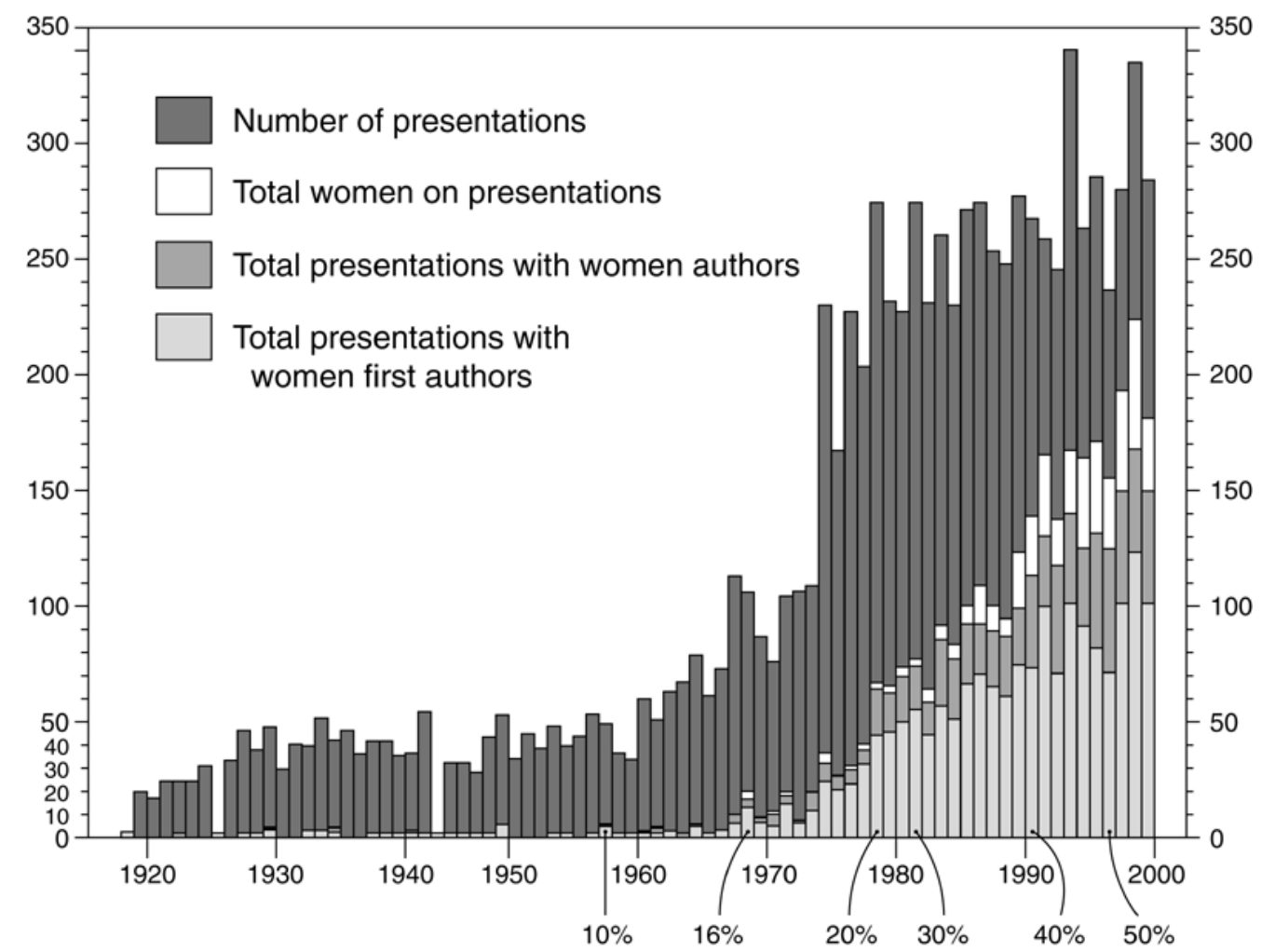

FIG. 2.- Relationship between total presentations (not percentages) at the annual meetings of the American Society of Mammalogists and total number of women authors on presentations, total number of presentations with women authors, and total number of presentations with women as 1st authors. Selected percentages of total presentations with women authors of the total number of presentations at the annual meeting are indicated.

respectively, had women authors (Fig. 2, Table 1). At the 49th annual meeting (1969), over $11 \%$ of the presentations had women as 1 st authors (this is considered an important measure because it usually is presumed that this person will be the presenter of the paper). The only other meetings before 1970 at which the $10 \%$ level of women 1 st authors was approached were at the 1933, 1950, and 1958 meetings at Harvard University, Yellowstone National Park, and University of Arizona, when the percentages reached $7.7 \%, 9.4 \%$, and $8.3 \%$, respectively (Fig. 1, Table 1).

From 1974 onward, women were authors (not just 1st authors) for over $10 \%$ of the presentations at the annual meeting. The $20 \%$ level of women's contribution quickly was reached in 1979, the $30 \%$ level was reached in 1981, and 40\% was passed in 1991 (Fig. 2, Table 1). Women have been authors on $50 \%$ or more of the contributions at the last 4 annual meetings (19972000).

Presentations with women as 1 st authors have demonstrated this same pattern, with the $10 \%$ level permanently being reached in 1974. Women were 1st authors of $20 \%$ of the presentations for the 1st time in 1981 and then permanently at that level beginning in 1984. Women were 1st authors of $30 \%$ or more of the presentations in 1992, 1995, 1998, 1999, and 2000, with the highest percentage being $37.8 \%$ at the meeting in 1992 at the University of Utah (Fig. 1, Table 1). 
We believe that the 2 trends seen in technical presentations at the annual meetings of the American Society of Mammalogists are interrelated. Both had their origins in the late 1960s, grew during the 1970s, and continued throughout the remainder of the century. It is clear that a large percentage of the great increase in presentations at the annual meetings have had women as authors, and a large number of these have had women as 1st authors. Clearly, the American Society of Mammalogists has benefited greatly from increased participation by women in the past 30 years, and this trend appears to be continuing.

\section{SYMPOSIA AND WORKSHOPS}

There have been 84 symposia, workshops, and similar events at the 80 annual meetings of the American Society of Mammalogists (Table 3). Symposia were an early feature of annual meetings, with the 1st concerning the "Anatomy and Relationships of the Gorilla," being held at the 4th annual meeting at the American Museum of Natural History in 1922. However, the holding of symposia and similar events occurred only intermittently until 1971, when they became regular features of the annual meeting. The 75th anniversary meeting of the Society held in 1994 was the venue for 5 symposia, the most held at any meeting.

Of the taxon-oriented symposia, marine mammals have proven to be the most popular subject, serving as the topic of 6. Rodents and predators-carnivores also have been popular subjects, each being the topic of 5 symposia. Other taxa that have been the topic of symposia at annual meetings include bats (4), prey-ungulates (3), primates (2) with both having the gorilla as the sole topic, and marsupials, insectivores, and elephants, each being the subject of 1 symposium. The most popular of the subject-oriented topics for symposia and workshops has been ecology, which has been the theme of at least 8 , and population ecology has been the topic of another 4. Other topics that have been covered in more than 1 sym- posium or workshop are systematics-evolution (6), behavior (4), biodiversity (4), careers in mammalogy (4), physiology (4), biogeography (3), genetics (3), manuscriptgrant preparation (3), conservation (2), and field techniques (2).

The number of women organizing and presenting in symposia has not been nearly as high as the number of men, nor has it increased, as is seen in technical papers and posters (Table 3). Of the 96 organizers and co-organizers of symposia and workshops, only 10 , or just over $10 \%$, have been women. The 1st woman to organize a symposium was Nancy Neff in 1980, and she was followed in 1985 by Suzanne McLaren, who is the only woman to organize more than 1 symposium or workshop. This is compared with 11 men who have organized or co-organized 2 or more of these events. Gary Barrett and Terry Bowyer each were responsible for organizing or co-organizing 3 symposia or workshops, whereas the following 9 men were responsible for 2: James Brown, Guy Cameron, John Eisenberg, Thomas Kunz, Duane Schlitter, Michael Smith, B. J. Verts, Don Wilson, and Jerry Wolff. Of the 449 participants in symposia or workshops at annual meetings, only 55 have been women, or only a little over $12 \%$. The 1 st woman to participate in an annual meeting symposium was Helen Price, who presented a paper titled "A Blood Fluke of Small Native Mammals" in the symposium on mammalian parasitology in 1929. The only symposium in which more than $50 \%$ of the participants were women was titled "Mammalian Social Evolution: A Female's Perspective" organized by Jan Randall in 1998 in which all participants were women.

\section{Poster Presentations}

Poster presentations were introduced to the annual meetings of the American Society of Mammalogists in 1979, when 15 posters were included in the program (Table 4). The 1st poster presented at an annual meeting was on the subject "Relative 
TABLE 3.- Titles and organizers of 84 symposia, workshops, and similar special features of the annual meetings of the American Society of Mammalogists.

\begin{tabular}{|c|c|c|}
\hline Year & Title & Organizer \\
\hline 1922 & Anatomy and Relationships of the Gorilla & W. K. Gregory \\
\hline 1923 & Field Methods of Collecting Specimens & H. E. Anthony \\
\hline 1924 & $\begin{array}{l}\text { The Scientific and Economic Importance of Predatory } \\
\text { Mammals }\end{array}$ & Committee on Life Histories \\
\hline 1925 & The Care of Mammal Material and Records & \\
\hline 1926 & Furs and Fur-Bearing Mammals & \\
\hline 1928 & Cetacea or Whales & Remington Kellogg \\
\hline \multirow[t]{2}{*}{1929} & Mammalian Genetics & C. C. Little \\
\hline & Mammalian Parasitology & G. R. La Rue \\
\hline \multirow[t]{2}{*}{1930} & Gorilla & \\
\hline & Utilization of Zoological Park Collections for Research & \\
\hline \multirow[t]{2}{*}{1942} & Bat Banding & Donald R. Griffin \\
\hline & Criteria for Vertebrate Subspecies, Species, and Genera & $\begin{array}{l}\text { Joint with American Society of Ichthyolo- } \\
\text { gists and Herpetologists and Society for } \\
\text { Vertebrate Paleontologists }\end{array}$ \\
\hline 1947 & Populations, Home Ranges, and Territories in Mammals & William H. Burt \\
\hline 1950 & Dynamics of Mammalian Populations & L. R. Dice \\
\hline 1951 & Predator-Prey Relationships & Antoon de Vos \\
\hline 1952 & Economic Mammalogy & Robert A. McCabe \\
\hline 1960 & Russian-American Exchanges in Mammalogy & E. W. Pfeiffer and R. S. Hoffmann \\
\hline 1961 & Pesticides and Herbicides & \\
\hline 1962 & Teaching Mammalogy at the University Level & W. J. Hamilton, Jr. \\
\hline 1964 & Anatomy and Physiology & L. C. Dearden \\
\hline 1971 & Marine Mammals & H. Dean Fisher \\
\hline \multirow[t]{2}{*}{1972} & Mammalian Behavior and Ecology: A Synthesis & John F. Eisenberg \\
\hline & Bottle-Nosed Dolphin Behavior & David K. Caldwell \\
\hline 1973 & Population Ecology of Small Mammals & Michael Smith and Guy Cameron \\
\hline 1974 & Locomotion in Mammals & Milton Hildebrand \\
\hline \multirow[t]{3}{*}{1975} & Mammalian Evolution & \\
\hline & $\begin{array}{l}\text { The Effects of Mammalian Populations on Ecosystems- } \\
\text { Utilization of Resources, Analysis of Benefits and En- } \\
\text { ergetics }\end{array}$ & Guy N. Cameron and Eugene D. Fleharty \\
\hline & Behavior and Interspecific Relations of Predators & Steven Herrero and Alan B. Sargeant \\
\hline \multirow[t]{2}{*}{1976} & $\begin{array}{l}\text { Physiological Adaptations of Mammals to Arid Environ- } \\
\text { ments }\end{array}$ & John M. Burns and Carleton J. Phillips \\
\hline & Ecological Aspects of Reproduction in Mammals & Walter Conley and Michael Smith \\
\hline \multirow[t]{2}{*}{1977} & Fossorial Mammals & Delbert L. Kilgore, Jr. \\
\hline & The Marsupial Alternative in Mammalian Radiation & John I. Johnson \\
\hline \multirow[t]{2}{*}{1978} & Marine Mammals & Daniel K. Odell and Thomas McIntyre \\
\hline & Mammalian Population Genetics & James Joule \\
\hline \multirow[t]{3}{*}{1979} & Career Trends in Mammalogy & Gary W. Barrett \\
\hline & Behavior and Ecology of African Small Mammals & Duane A. Schlitter \\
\hline & Elephants & Jeheskel Shoshani \\
\hline \multirow[t]{3}{*}{1980} & Numerical Methods in Systematic Mammalogy & Nancy A. Neff and Duane A. Schlitter \\
\hline & Social Organization in Microtine Rodents & Jerry O. Wolff \\
\hline & Physiological Ecology of Peromyscus & Richard W. Hill \\
\hline 1981 & Ecology of Bats & Thomas H. Kunz \\
\hline \multirow[t]{3}{*}{1982} & Biology of New World Microtines & Robert H. Tamarin \\
\hline & Biology of Desert Rodents & James H. Brown \\
\hline & Reviewing Manuscripts for the Journal of Mammalogy & B. J. Verts and D. E. Wilson \\
\hline \multirow[t]{3}{*}{1983} & Preparing and Reviewing Proposals in Mammalogy & Gary Barrett and Don Kaufman \\
\hline & Biogeography of Southeast Asian Mammals & Illar Muul \\
\hline & Mammal Conservation Issues & Ralph M. Wetzel and John F. Eisenberg \\
\hline 1984 & Marine Mammals & Thomas J. O'Shea \\
\hline
\end{tabular}


TABle 3.-Continued.

\begin{tabular}{|c|c|c|}
\hline Year & Title & Organizer \\
\hline \multirow[t]{2}{*}{1985} & Microcomputers Applicability to Mammalian Studies & Suzanne McLaren \\
\hline & Patterns of Diversity and Areography & Bruce Patterson and James Brown \\
\hline \multirow[t]{2}{*}{1986} & The Evolution of the Carnivora & W. Chris Wozencraft \\
\hline & $\begin{array}{l}\text { Ungulates: Their Role in the Development of Ecological } \\
\text { and Evolutionary Theory }\end{array}$ & R. Terry Bowyer \\
\hline \multirow[t]{3}{*}{1987} & Animal Welfare & Gary W. Barrett \\
\hline & Historical Zoogeography of Southwestern Mammals & David J. Hafner and Robert M. Sullivan \\
\hline & Biology of the Soricidae & $\begin{array}{l}\text { Sarah B. George, James S. Findley, and } \\
\text { Gordon L. Kirkland, Jr. }\end{array}$ \\
\hline \multirow[t]{2}{*}{1988} & $\begin{array}{l}\text { Physiology, Ecology, and Life-History Patterns in Ro- } \\
\text { dents }\end{array}$ & Teresa H. Horton and Edward B. Pivorun \\
\hline & Comparative Energetics & Thomas E. Tomasi \\
\hline \multirow[t]{4}{*}{1989} & The Biopolitics of Conservation & Gary A. Heidt \\
\hline & $\begin{array}{l}\text { Ecology, Physiology, and Evolution of Alaskan Mam- } \\
\text { mals }\end{array}$ & D. R. Klein and R. T. Bowyer \\
\hline & Ontogeny and Mammalian Evolution & Donald O. Straney and Phil Brylski \\
\hline & Preparation of Tables and Figures & Clyde Jones and B. J. Verts \\
\hline \multirow[t]{2}{*}{1990} & Behavior, Ecology, and Conservation of Bats & Thomas H. Kunz \\
\hline & Biological Monitoring with Mammals & Greg Linder and Karen McBee \\
\hline 1991 & $\begin{array}{l}\text { Application of Geographic Information Systems (GIS) to } \\
\text { Mammalogy }\end{array}$ & $\begin{array}{l}\text { Suzanne B. McLaren, Paul F. Steblein, and } \\
\text { Peter V. August }\end{array}$ \\
\hline 1992 & Forum on Women and Minorities in Science & $\begin{array}{l}\text { ad hoc Committee on Women and Minority } \\
\text { Issues }\end{array}$ \\
\hline \multirow[t]{2}{*}{1993} & $\begin{array}{l}\text { "So You Want To Be a Professor? How Women and Mi- } \\
\text { norities Succeed in the Tenure Mainstream" }\end{array}$ & $\begin{array}{l}\text { ad hoc Committee on Women and Minority } \\
\text { Issues }\end{array}$ \\
\hline & Developing a Career in Mammalogy & $\begin{array}{l}\text { Committee on Education and Graduate Stu- } \\
\text { dents }\end{array}$ \\
\hline \multirow[t]{5}{*}{1994} & $\begin{array}{l}\text { Biodiversity at the Cellular/Organismic Level of Organi- } \\
\text { zation }\end{array}$ & Robert Lacey \\
\hline & Biodiversity at the Population Level of Organization & David E. Schmidly \\
\hline & Biodiversity at the Community Level of Organization & O. James Reichman \\
\hline & $\begin{array}{l}\text { Biodiversity at the Ecosystem/Landscape Levels of Or- } \\
\text { ganization }\end{array}$ & Michael Bowers \\
\hline & $\begin{array}{l}\text { Careers in Mammalogy: Is There Life Outside the Ivory } \\
\text { Tower }\end{array}$ & Barbara R. Stein \\
\hline \multirow[t]{2}{*}{1995} & Evolutionary Patterns in the Carnivora & \\
\hline & $\begin{array}{l}\text { Beyond Reductionism: Multifactorial Approaches to } \\
\text { Mammalian Ecology }\end{array}$ & Richard S. Ostfield and Jerry O. Wolff \\
\hline \multirow[t]{2}{*}{1996} & Endocrine Disruptors: Hidden Threats to Wildlife & Michael Smolen \\
\hline & Echolocation in Mammals & Jeanette Thomas \\
\hline 1997 & Social Structure and Gene Dynamics & Steve Dobson \\
\hline \multirow[t]{3}{*}{1998} & ASM Career Opportunities & Robert Manson \\
\hline & Mammalian Social Evolution: A Female's Perspective & Jan A. Randall \\
\hline & $\begin{array}{l}\text { Life History Strategies of Ungulates: An Evolutionary } \\
\text { Perspective }\end{array}$ & R. Terry Bowyer and John G. Kie \\
\hline \multirow[t]{2}{*}{1999} & Bat Detection & William Gannon \\
\hline & Marine Mammals & Paul Anderson \\
\hline \multirow[t]{2}{*}{2000} & How to Get the Most Out of Your ASM Membership & Christine L. Hice \\
\hline & $\begin{array}{l}\text { Movements as a Link between Behavior and Landscape } \\
\text { Ecology: Mammals as Models }\end{array}$ & Patrick Zollner \\
\hline
\end{tabular}


TABLE 4.- Number of poster presentations at the annual meetings of the American Society of Mammalogists and their impact on contributions of women to the technical presentations.

\begin{tabular}{rcccccc}
\hline Year & $\begin{array}{c}\text { Total number } \\
\text { of posters }\end{array}$ & $\begin{array}{c}\text { Percentage of } \\
\text { posters of total } \\
\text { presentations }\end{array}$ & $\begin{array}{c}\text { Number of } \\
\text { posters with } \\
\text { women as } 1 \text { st } \\
\text { authors }\end{array}$ & $\begin{array}{c}\text { Percentage of } \\
\text { posters with } \\
\text { women 1st } \\
\text { authors }\end{array}$ & $\begin{array}{c}\text { Total number of } \\
\text { posters with } \\
\text { women authors }\end{array}$ & $\begin{array}{c}\text { Percentage of } \\
\text { posters with } \\
\text { women authors }\end{array}$ \\
\hline 1979 & 15 & 5.5 & 5 & 33.3 & 5 & 33.3 \\
1980 & 27 & 11.7 & 3 & 11.1 & 8 & 29.6 \\
1981 & 21 & 9.3 & 7 & 33.3 & 10 & 47.6 \\
1982 & 30 & 10.9 & 7 & 23.3 & 10 & 33.3 \\
1983 & 23 & 10.0 & 7 & 30.4 & 8 & 34.8 \\
1984 & 35 & 13.5 & 10 & 28.6 & 15 & 42.9 \\
1985 & 35 & 15.3 & 9 & 25.7 & 13 & 37.1 \\
1986 & 53 & 19.6 & 15 & 28.3 & 21 & 39.6 \\
1987 & 44 & 16.1 & 19 & 43.2 & 24 & 54.5 \\
1988 & 54 & 21.3 & 15 & 27.8 & 22 & 40.7 \\
1989 & 54 & 21.9 & 16 & 29.6 & 23 & 42.6 \\
1990 & 67 & 24.3 & 26 & 38.8 & 32 & 47.8 \\
1991 & 69 & 25.9 & 21 & 30.4 & 36 & 52.2 \\
1992 & 86 & 33.2 & 40 & 46.5 & 55 & 64.0 \\
1993 & 65 & 26.6 & 17 & 26.2 & 36 & 55.4 \\
1994 & 195 & 57.4 & 69 & 35.4 & 94 & 48.2 \\
1995 & 72 & 27.4 & 30 & 41.7 & 41 & 56.9 \\
1996 & 95 & 33.3 & 35 & 36.8 & 50 & 52.6 \\
1997 & 78 & 33.1 & 27 & 34.6 & 47 & 60.3 \\
1998 & 80 & 28.7 & 33 & 41.3 & 51 & 63.8 \\
1999 & 145 & 43.3 & 60 & 41.4 & 80 & 55.2 \\
2000 & 94 & 33.2 & 37 & 39.4 & 55 & 58.5 \\
\hline & & & & & & \\
\hline
\end{tabular}

Abundance and Ecological Distribution of Shrews in Mississippi" by James L. Wolfe and Robert L. Esher. The 1st woman to present a poster was Ellen Kritzman, who was

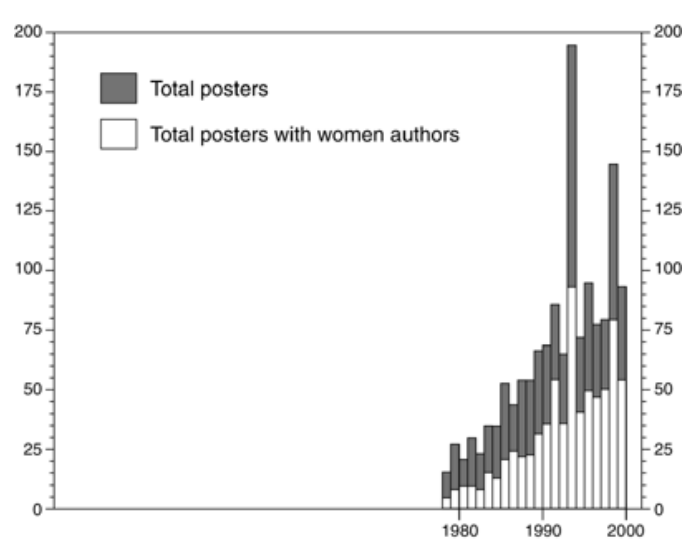

FIG. 3.-Relationship between total number of posters at the annual meetings of the American Society of Mammalogists and total number of posters with women authors. 1st author on a paper with Murray L. Johnson on "Breeding Strategies of Three Species of Mice in Eastern Washington," also in Poster Session I at the 1979 meeting. From this modest beginning, the number of posters has risen to a high of 195 posters at the meeting in 1994 and 145 in 1999. At most meetings since 1992, posters have accounted for $33 \%$ or more of the presentations at the annual meeting. The poster venue has been particularly popular with women members of the Society. Every year since posters were introduced, the percentage of posters with women authors (Table 4) has been higher than the percentage of all technical presentations (Table 1) with women authors (Fig. 3). With the exception of 2 years $(1980,1993)$, this same fact is true for presentations with women as 1 st authors. These data suggest that the introduction of poster sessions is a good strategy for scientific organizations wishing to at- 
tract more contributions from women at their annual meetings.

\section{Business MeEtings}

The annual meeting traditionally has been the venue for the board of directors and the membership to conduct the business of the Society. The program of the 2nd annual meeting listed a membership business meeting, and the program for the 3rd meeting listed a board meeting preceding the opening of the technical sessions and 2 membership business meetings. That pattern has remained in place through the 80th annual meeting, with only a 2 nd meeting of the board of directors being formally added in 1971 as a luncheon following the 2nd membership meeting.

\section{Special Features}

Resolutions.-A Resolutions Committee was established by the Society in 1956 (Gill and Wozencraft 1994), but resolutions were a regular feature of annual meetings long before that time. Resolutions have been passed by the American Society of Mammalogists to thank members for special service, such as hosting an annual meeting, and to make public statements on issues for which members possess special expertise and concern. The 1st record of the latter type of resolution that we were able to find was 2 passed at the 6th annual meeting in 1924 (Jackson 1924). The 1st resolution was a statement in opposition to the "destruction of so-called 'vermin' and predatory mammals," and the 2nd was endorsement of United States House and Senate bills introduced to ensure "the future welfare and preservation of Alaska wild life." The following year, a resolution was passed opposing the introduction of "large numbers of Plains Buffaloes annually into the Wood Buffalo Park of northern Alberta" (Howell 1925). Those resolutions give a good sense of the strong positions on conservation of wild mammals that the Society has taken in many of its resolutions.

Annual banquet.-The origins of the an- nual banquet are not particularly clear, but by the 8th annual meeting in 1926, an "Annual dinner of the Society" was listed in the meeting program (Howell 1926). The 1st annual meeting featured 2 luncheons for members and an "Informal program and conversazione" in the evening. The 2nd, $3 \mathrm{rd}$, 5th, and 6th meetings seemed to feature only luncheons. There was an evening dinner at the 4th annual meeting held at the Hotel San Remo in New York City (Jackson 1922). A dinner also was held at the 7 th annual meeting, but it was not listed in the program. For the dinner on 9 April 1925, "the main item upon the menu was roast buffalo, while elk meat figured at the luncheon, April 11" (Howell 1925). Roast elk reappeared on the menu of the annual banquet at the meeting in Toronto in 1948. It was accompanied by Cumberland sauce, duchesse potatoes, and green peas, preceded by assiette parisian and essence of tomato, and followed by Madeleine glace and petits fours. Some of the more ambitious banquets in recent years have been those at the University of Wisconsin in 1986, at which duck in orange sauce was served, and those at the University of Maine in 1985 and University of New Hampshire in 2000, when whole Maine lobsters were the main event. One of the more interesting venues for an annual banquet was at the 1969 meeting, when Society members dined on the floor of the Hall of Ocean Life at the American Museum of Natural History directly under the stunning replica of a 94-foot-long female blue whale suspended from the ceiling.

Many of the banquets included various types of entertainment. Typical entertainment included films, lectures, and performing artists, such as dancers or musicians. The funniest banquet program recalled by older members of the Society was one that W. H. Osgood arranged for the Chicago meeting in 1941. Emil Liers came with his tame otters and released them to run around in the banquet room for everyone to pet. Liers wanted to demonstrate that otters did 
not eat fish, so he installed up front a huge glass-fronted tank filled with water and stocked with large gold fish. To his dismay, when he introduced his clever otters into the tank, they immediately started eating the goldfish. Among the more memorable lectures in recent years was that by Randolph Peterson at Colorado State University in 1968 that lasted over an hour on his work in Madagascar after a very long "happy hour" before the banquet and a very large meal including shrimp cocktail, rib-eye steak, and baked potato. We were shown all the rolled leaves on Madagascar that were potential hiding places for Myzopoda aurita without actually ever seeing a bat. The crush at the nearby restrooms following the banquet was epic. There was the lecture by Durwood Allen at Michigan State University in 1977 on moose-wolf interaction on Isle Royale. We had the "privilege" of seeing enough half-eaten moose kills that Dr. Bernardo Villa went to sleep and fell from his chair. In a far more positive light, the talk by Dorcas MacClintock on the history of nature illustrations featuring mammals at the meeting in 1986 was quite charming, as was the unusually humorous presentation by Sydney Anderson in 1976. In recent years, postbanquet activities have been filled by the presentation of the Merriam, Jackson, and Grinnell Awards as well as student grants-in-aid, honoraria, and the Shadle Award.

Some annual banquets included a quiz to test participants' mammalogical knowledge or, as the quiz from 1941 stated, "If you are a mammalogist, prove it!" The 1941 quiz was composed of 22 questions, including such questions as "When was the Okapi discovered?" to "What are the most prolific mammals?" Rollin H. Baker received the Explorers Club book titled Through Hell and High Water, which contains an adventure article by Wilfred $\mathrm{H}$. Osgood titled "Youthful Adventure" and autographed by him to Baker as "winner" of the 1941 meeting banquet-staged quiz. The quiz for 1951 was "Who Wrote What?" with 30 questions, beginning with "Who wrote Quadrupeds of North America?" and ending with "Who wrote A Monograph of the Bats of North America?" The quiz for 1956 was identification of a photograph revealing about one-third of some species of mammal.

Honorary members.-Honorary membership is bestowed by the American Society of Mammalogists to recognize a "distinguished record of achievement" in the science of mammalogy (Taylor and Schlitter 1994). Traditionally, this is the highest honor that the Society bestows and is presented to a fellow scientist during the 1 st business meeting of the annual meeting. This has been a feature of the annual meeting since its inception, when Joel Asaph Allen was honored during the 1st annual meeting in 1919. That was followed by the honoring of Edouard-Louis Trouessart in 1921 (Jackson 1921). Sixty-seven mammalogists have been honored by the Society through its first 80 annual meetings. Recipients have come from the following countries: United States (43), England (4), Germany (3), Russia (3), China (2), France (2), Mexico (2), Australia (1), Canada (1), Denmark (1), Finland (1), Japan (1), Norway (1), Poland (1), and Spain (1). Only 1 of the recipients was a woman-Erna Mohr, elected in 1966 (for a list of recipients, see Taylor and Schlitter 1994).

Honoraria.-The Society currently awards 3 honoraria to students to enable them to attend the annual meeting and present the results of their research. The Society awarded the 1st honorarium in 1955 to Phillip M. Youngman, allowing him to report on his research on "A Population of the Striped Field Mouse, Apodemus agrarius mantchuricus, in Central Korea." The 1st women to receive an honorarium was Patricia J. DeCoursey, who gave a presentation on "Daily Activity Rhythms in Glaucomys volans" at the annual meeting in 1958. The 1st named honorarium appeared in the program for the annual meeting in 1962. Edwin Gould was given the Ameri- 
can Society of Mammalogists Award to present his research on "Evidence for Echolocation in Shrews," and David I. Rasmussen received the A. Brazier Howell Award to present his research on "Antigenic Polymorphism and Inbreeding in Natural Populations of the Woodland Deer Mouse, Peromyscus maniculatus gracilis." A. Brazier Howell was a longtime employee of the United States Biological Survey, 2nd corresponding secretary of the Society, and 13th president, serving from 1942-1944. The 3rd named honorarium, the Anna M. Jackson Award, was given 1st to Earl G. Zimmerman in 1970 to present "Cytotaxonomy of the Genus Sigmodon." Anna M. Jackson was the wife of H. H. T. Jackson and was credited with tirelessly assisting him in the initial organization of the American Society of Mammalogists and its early years of operation. As discussed earlier, the honoraria presentations are now given in the plenary session that opens each annual meeting.

Photographs. - Group photographs of the attendees at the annual meeting have been a feature since the initial meeting in 1919 (Figs. 4 and 5). Although the group photograph does not officially appear in the program until the 7 th annual meeting in 1925 (Journal of Mammalogy 6:plate 18, following p. 216, 1925) and then not again until the 17th meeting, photographs of many of the earlier meetings are available. Although this would seem to be a rather mundane activity for a scientific society, it usually results in the most confusion and laughter of any activity at the meeting. Trying to get several hundred mammalogists to arrive on time, get into lines, look at the photographer, hold still for a few seconds, and then wait in place to sign their names on a list so they can be identified in the photograph will try the patience of even the most experienced photographer's assistant and Local Committee. The sign-up sheets reveal a unique phenomenon of the annual group photograph-C. Hart Merriam and
Vernon Bailey appear each year to be in the photograph.

Films.-Films have been a feature of many meetings of the Society, especially in the earlier years, when this was the latest technology. The 2nd annual meeting featured 2 motion pictures - on sea lions of the Peruvian coast, presented by Robert Cushman Murphy, and the Second Asiatic Expedition to China and Mongolia, presented by Roy Chapman Andrews-shown in the evening of the 1st day of the meeting (Jackson 1920). From the 2nd annual meeting through the 43rd in 1963, it appears that only 2 meetings $(1924,1954)$ did not include film presentations. One of the more interesting presentations was the showing of the United Artists film Elephant Boy at the 1937 meeting in Washington, D.C. After 1963, films became much less common at meetings, but 2 films from this time period that are fondly remembered were the film of a newborn kangaroo crawling to its mother's pouch, presented by Hobart Van Duesen, and the first film of the social behavior of naked mole rats, presented by Jennifer Jarvis. The most recent film that appeared in the meeting program was the video The Last Roundup shown at the 68th annual meeting held at Clemson University.

Tours.-Tours and field trips were a regular feature of the meetings until the Society went to 4 days of technical sessions in 1976. Many of these were daylong tours on the last day of the meetings. Even at the 1st annual meeting, members went to the National Zoological Park for the final afternoon. Zoos, research laboratories, aquaria, caves, viewings of wildlife, and other points of local interest were the usual subject of tours and field trips.

Picnics.-At recent meetings, picnics have largely replaced tours and field trips because they can be done in late afternoon and evening. This tradition nearly ended before it started in 1976 when members were almost swept away by a West Texas thunderstorm on the bus trip from Lubbock to 


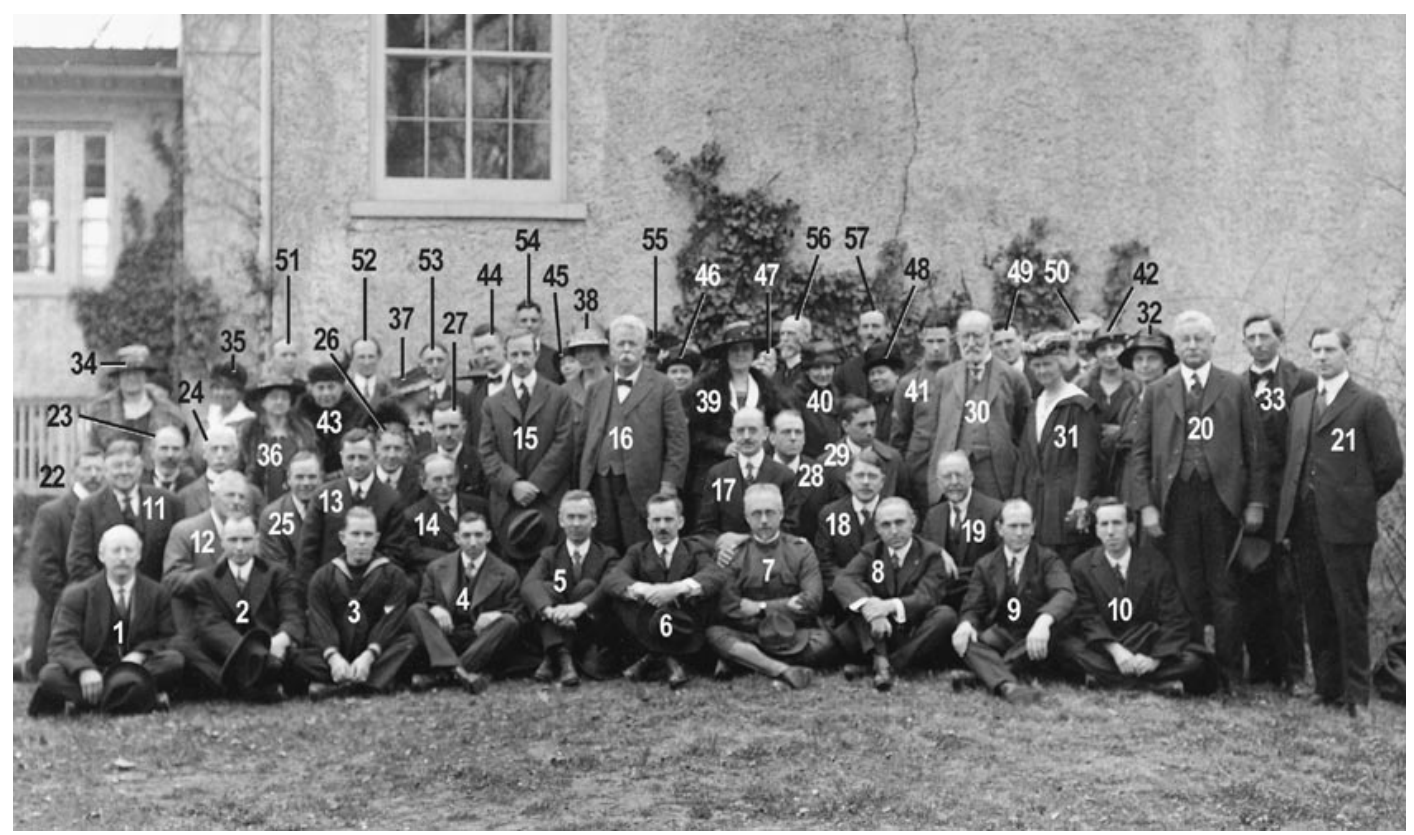

FIG. 4.- Photograph of the participants in the 1st annual meeting of the American Society of Mammalogists, United States National Museum, Washington, D.C., 1919. The individuals in the photograph are as follows: 1) Chas. H. M. Barrett; 2) Walter P. Taylor; 3) Chas. M. Hoy; 4) Arthur J. Poole; 5) Vernon Bailey; 6) Ned Hollister; 7) M. W. Lyon, Jr.; 8) George A. Lawyer; 9) Frank N. Jarvis; 10) H. H. T. Jackson; 11) A. K. Fisher; 12) Leo D. Miner; 13) William B. Bell; 14) Witmer Stone; 15) W. H. Osgood; 16) C. Hart Merriam; 17) J. W. Gidley; 18) C. C. Adams; 19) George W. Field; 20) E. W. Nelson; 21) Walter C. Henderson; 22) Ned Dearborn; 23) T. S. Palmer; 24) C. F. Batchelder; 25) Chas. Sheldon; 26) Edward A. Preble; 27) R. M. Anderson; 28) William H. Cheesman; 29) James S. Gutsell; 30) Henry W. Henshaw; 31) Mrs. M. W. Lyon, Jr; 32) Mrs. H. H. T. Jackson; 33) H. H. Lane; 34) Mrs. Witmer Stone; 35) Mrs. T. S. Palmer; 36) Mrs. E. A. Preble; 37) Mrs. F. Merriam Bailey; 38) Mrs. Waldo Schmitt; 39) Mrs. J. W. Gidley; 40) Mrs. Ned Hollister; 41) Leland C. Wyman; 42) Miss Viola S. Schantz; 43) Mrs. C. Hart Merriam; 44) Waldo L. Schmitt; 45) Mrs. Leo D. Miner; 46) Miss May T. Cooke; 47) J. W. Scollick; 48) Mrs. Jane S. Elliott; 49) J. Warren Craven; 50) William Palmer; 51) A. B. Baker; 52) Harry C. Oberholser; 53) B. H. Swales; 54) Alexander Wetmore; 55) Miss Katherine B. Baird; 56) Jonathan Dwight, Jr.; 57) John P. Buwalda.

Canyon, Texas, for the picnic and the stage play Texas.

There are several rules that must be observed at the annual picnic. Do not get near the front of the food line because you can be crushed in the panic of trying to be fed by the Oklahoma State University food service when they funneled all 700 members of the Society through a single line! Do not be near the end of the line because your fresh-off-the-grill buffalo burger at the National Bison Range can turn into a cold hamburger because the main course runs out at a meeting at the University of Montana! Do not get between the mammalogists and the beer at any picnic! Dress warmly because our colleagues at places like Frostburg State University can find a winter spot for a picnic even in June! One question remains from the 2000 picnic: Do one weenie and a hamburger really cost $\$ 25$ in New Hampshire?

Exhibitions.-Some of the annual meetings have been accompanied by exhibitions. A special feature of the meeting in 1922 was the dedication of the North American 


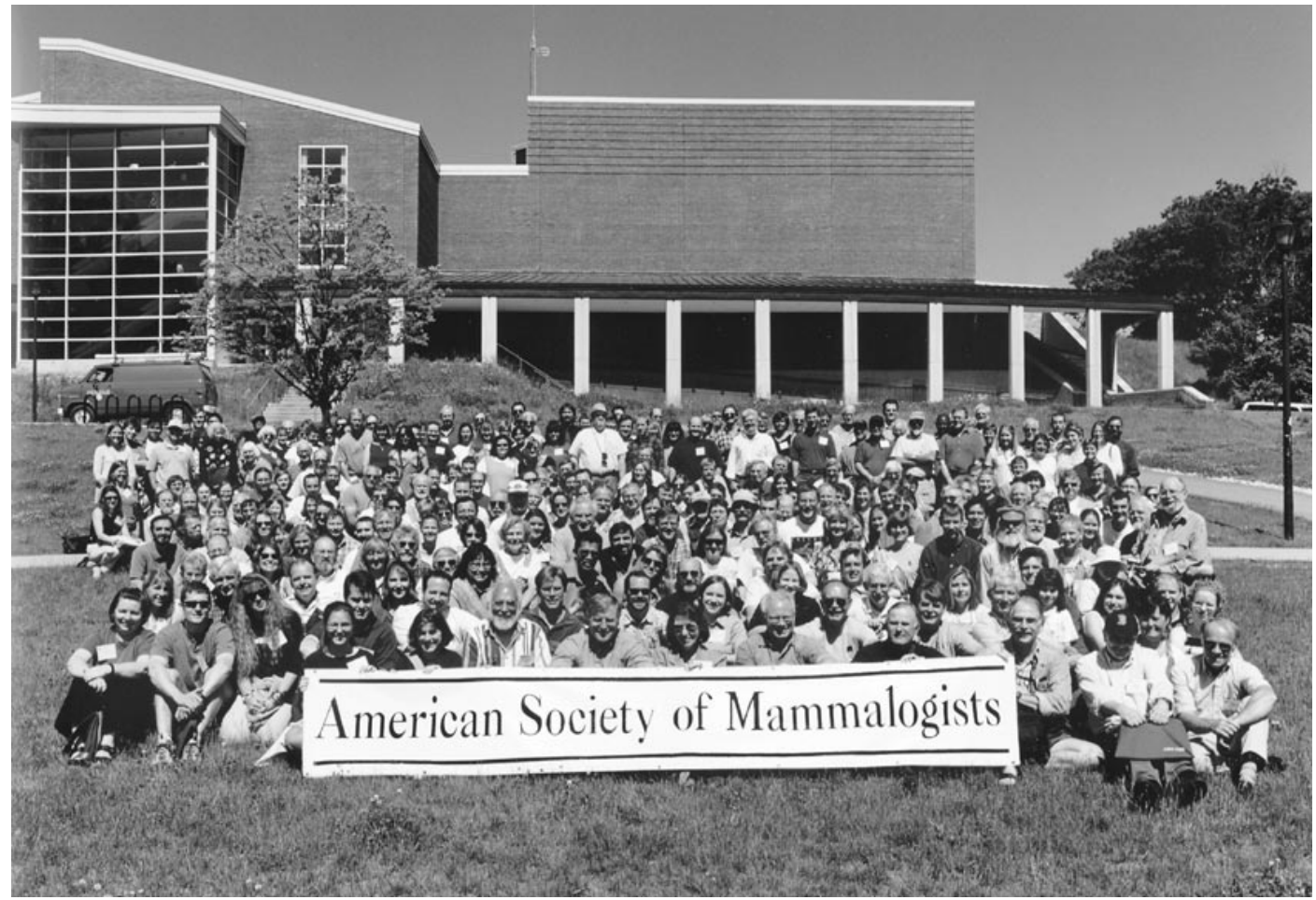

FIG. 5.-Photograph of the participants in the 80th annual meeting of the American Society of Mammalogists, University of New Hampshire, Durham, New Hampshire, 2000.

Mammal Hall of the American Museum of Natural History to the memory of J. A. Allen, lead by the president of the Museum and world-renowned vertebrate paleontologist Henry Fairfield Osborn. At this same meeting, there was a contest for photographs of mammals in which 1,700 photographs submitted by 140 people were entered. John M. Phillips won the contest for photographs of mammals in the wild state and Elwin R. Sanborn for mammals in captivity. Among the other award winners were Carl E. Akeley and Kermit Roosevelt (Jackson 1922). One of the more elaborate exhibitions was at the 10th annual meeting, when 4 exhibits were displayed including works of mammal artists, fossil whales, Recent whales, and small traps and trapping. The art exhibit was particularly impressive with 1 part for paintings and drawings of living mammals and another for scientific illustrations for publications. Artists includ- ed in the exhibition that should be readily recognized even today were Louis Agassiz Fuertes, O. J. Murie, Ernest Thompson Seton, Francis Lee Jaques, and Carl Rungius (Howell 1928). Other meetings featured exhibitions of apparatuses used in the care and study of live mammals in the laboratory (1930); photographic art of wild animals (1938); flash-light photographs of mammals (1941); paintings and photographs of vertebrate animals $(1942,1946) ; 5$ and 7 displays, respectively, on mammalian research (1971, 1972); paintings of wildlife and western scenes and photographs of Montana wildlife (1975); and the history of the Society and mammalogy (1994).

Auction.-The annual auction is a fundraising activity that has seen the sale of a range of items from mammalogical memorabilia to truly valuable books and wall charts to someone's trash that they hope will be someone else's treasure. The annual 
auction had a rather ignominious origin in providing the seed funds for liquid libations at the next year's annual meeting, being operated by the ad hoc Beer Committee, which proved to be a popular and hardworking committee. The auction was started in 1977 with Thomas McIntyre driving the beer truck and Greg Blair auctioning a case, can by can, of Old Frothingslough, "the Pale Stale Ale with the Foam on the Bottom," produced by the Pittsburgh Brewing Company. The annual auction made its 1st appearance in the official program in 1987 and has been serving a nobler cause by providing endowment funds for the $\mathrm{Fu}-$ ture Mammalogists Fund, which is part of the Reserve Fund used to support programs, including honoraria and grants-in-aid, for student members. Recent auctions have been highly successful, netting more than $\$ 3,000$ annually for the Fund with the dedicated and hilarious service of Frank Fish and Thor Holmes, both members and auctioneers.

Smokers.-It now seems curious looking back at old programs and seeing an activity listed as a "Smoker." It is even more curious to see that the last Smoker was listed in the 1969 program for the meeting in New York. The 1932 Smoker was described as follows: "there will be a Smoker for the smokers, and Conversazione for the conversationalists and their wives in the Foyer of the U.S. National Museum."

Run for Research.-The Run for Research first appeared in the official program at the annual meeting in 1987 at the University of New Mexico. This was a function initiated by Dwight Moore and carried forward by Gordon L. Kirkland, Jr., to promote friendly competition, encourage fitness, and raise funds for the Future Mammalogists Fund through entry fees. The Run for Research was named for Dr. Kirkland in 1999 and became an official Society function at the annual meeting in 2000. The run in 1999 had over 50 participants and garnered over $\$ 2,000$ for the Fund.
Spilogale.-The Spilogale, A Journal of Asinology, accepting any asinine, absurd, and abase articles, made it first appearance at the meeting in Baton Rouge, Louisiana, in 1939. It has continued its irreverent and irrelevant periodic appearances at annual meetings since that time. The Spilogale probably had its origins in Auklet, produced by our colleagues of the feathered persuasion, and was reinforced by the 1946 joint meeting with American Society of Ichthyologists and Herpetologists, which preceded the appearance of the 2 nd issue of The Spilogale at the meeting in Toronto in 1948. Our lower-vertebrate colleagues issued volume 4 of ICHTHERPS, A Cold-Blooded Journal of Vertebrates, at the joint meeting in 1946.

\section{CONCLUSIONS}

The annual meetings of the American Society of Mammalogists have served as a primary forum for the presentation and discussion of research on mammals. In the 82 years since the founding of the Society in 1919 , it has held 80 annual meetings, missing only 2 years during World War II. It was not until the 48th annual meeting in 1968 that the number of presentations exceeded 100. There has been an explosion of the number of presentations at the annual meeting in the years since 1968, partly by adding poster sessions in 1979. In 2 recent years, the number of presentations has exceeded $300-340$ at the 74th annual meeting in 1994 and 335 at the 79th meeting in 1999. Concomitant with the explosion of total presentations at the meetings has been the rise in the number of presentations by women scientists at the meetings. At recent meetings, women have been authors on over $50 \%$ of the presentations with over $37 \%$ of the presentations by women as $1 \mathrm{st}$ authors. However, women are not as well represented as organizers $(10.4 \%)$ or as invited participants $(12.2 \%)$ in symposia.

The annual meetings have served as the venue for conducting the business of the 
Society. The business meetings of the Society have changed little from the initial pattern established by 3rd annual meeting. A formal 2nd meeting of the board of directors was added in 1971 as the business activities of the Society became more complex.

Possibly the most important function of the annual meeting has been the intangible building of esprit de corps among members of the Society. This has led to a sense of a mammalogical community, joint research among members, promotion of young mammalogists, the championing of conservation issues concerning mammals, leadership among professional societies in specimen and database management, and the building of a financially strong Society with a commitment to the publication of mammalogical research. This cohesiveness has been built by many of the informal activities of the annual meeting as well as the small informal discussion groups that spontaneously develop at many of the sites around the venue of the annual meeting.

\section{ACKNOWLEDGMENTS}

We particularly express our gratitude to A. L. Gardner, archivist for the American Society of Mammalogists, for his help in many ways on this project, including working with the Smithsonian Archives to get copies of many of the early annual meeting programs, for providing an electronic copy of the photograph of the 1 st annual meeting of the Society, and for reading and making significant corrections to an earlier draft of this manuscript. We appreciate the comments and improvements made in an earlier draft of the manuscript by our colleagues D. E. Wilson, J. M. Taylor, R. H. Baker, J. R. Choate, C. J. Kirkland, and T. J. McIntyre. We also acknowledge the ongoing efforts of the archivists of the Smithsonian Institution for maintenance of the archives of the American Society of Mammalogists and for providing copies of appropriate material necessary for this manuscript. A. Fox, technical artist, University of Nebraska State Museum, prepared final copy of the figures. This manuscript was prepared as part of the duties of the office of historian of the Society.

\section{LiterAture Cited}

BiRNEy, E. C., AND J. R. ChOATE (EDS.). 1994. Seventyfive years of mammalogy. Special Publication, American Society of Mammalogists 11:xiv + 1433.

DAvis, W. B. 1969. The American Society of Mammalogists Permanent Fund: a special report of the Trustees. Pp. 33-40 in 50th Anniversary Celebration of the American Society of Mammalogists, 19191969 (R. G. Van Gelder, chair, Local Committee). American Society of Mammalogists, Stillwater, Oklahoma.

Gill, A. E., AND W. C. Wozencraft. 1994. Committees and annual meetings. Pp. 155-170 in Seventyfive years of mammalogy (E. C. Birney and J. R. Choate, eds.). Special Publication, American Society of Mammalogists 11:xiv + 1-433.

HofFmeister, D. F. 1969a. The first fifty years of the American Society of Mammalogists. Journal of Mammalogy 50:794-802.

HoffMeister, D. F. 1969b. A history of the American Society of Mammalogists. Pp. 8-15 in 50th Anniversary Celebration of the American Society of Mammalogists, 1919-1969 (R. G. Van Gelder, chair, Local Committee). American Society of Mammalogists, Stillwater, Oklahoma.

HoffMeister, D. F., AND K. B. Sterling. 1994. Origin. Pp. 1-21 in Seventy-five years of mammalogy (E. C. Birney and J. R. Choate, eds.). Special Publication, American Society of Mammalogists 11:xiv + $1-433$.

Howell, A. B. 1925. Seventh annual meeting of the American Society of Mammalogists. Journal of Mammalogy 6:213-216.

Howell, A. B. 1926. Eighth annual meeting of the American Society of Mammalogists. Journal of Mammalogy 7:237-241.

Howell, A. B. 1928. Tenth annual meeting of the American Society of Mammalogists. Journal of Mammalogy 9:175-178.

JACKSON, H. H. T. 1920. Second annual meeting of the American Society of Mammalogists. Journal of Mammalogy 1:199-200.

JACKSON, H. H. T. 1921. The third annual meeting of the American Society of Mammalogists. Journal of Mammalogy 2:184-186.

JACKSON, H. H. T. 1922. Fourth annual meeting of the American Society of Mammalogists. Journal of Mammalogy 3:199-203.

JACKSON, H. H. T. 1923. Fifth annual meeting of the American Society of Mammalogists. Journal of Mammalogy 4:205-207.

JACKSON, H. H. T. 1924. Sixth annual meeting of the American Society of Mammalogists. Journal of Mammalogy 5:218-219.

TAYlOR, J. M., AND D. A. SchlitTer. 1994. Awardees. Pp. 71-109 in Seventy-five years of mammalogy (E. C. Birney and J. R. Choate, eds.). Special Publication, American Society of Mammalogists 11:xiv + $1-433$.

Submitted 2 January 2001. Accepted 10 January 2001.

Associate Editor was David M. Leslie, Jr. 